\title{
Is There a Relationship Between Biochemical Recurrence and Insulin-like Growth Factor-1 in Patients with Surgical Border Negative Radical Prostatectomy?
}

\section{Cerrahi Sinır Negatif Radikal Prostatektomili Hastalarda Biyokimyasal Nüks ile İnsülin Benzeri Büyüme Faktör-1 Arasında İlişki Var mıdır?}

\author{
Yusuf Kasap®, Emre Uzun®, Bugra Bilge Keseroglu®, Sedat Tastemur®, Cavit Ceylan®, Muhammed Emin Polat (D)
}

Department of Urology, University of Health Sciences, Ankara City Hospital, Ankara, Turkey

Cite as: Kasap Y, Uzun E, Keseroglu BB, Tastemur S, Ceylan C, Polat ME. Is there a relationship between biochemical recurrence and insulin-like growth factor-1 in patients with surgical border negative radical prostatectomy? Grand J Urol 2021;1(2):43-8.

Submission date: 22 December 2020 Acceptance date: 17 March $2021 \quad$ Online first: 05 April $2021 \quad$ Publication date: 20 May 2021

Corresponding Author: Yusuf Kasap / University of Health Sciences, Ankara City Hospital, Department of Urology, Ankara, Turkey / dryusuf85@hotmail.com ORCID ID: 0000-0001-5313-2611

\begin{abstract}
Objective: Levels of insulin-like growth factor 1 (IGF-1) have been associated with prostate carcinoma. We have investigated whether IGF-1 level has an early predictive value for the biochemical relapse in the prostate carcinoma patients with a negative surgical margin who underwent curative surgery.

Materials and Methods: We retrospectively analyzed 82 patients who were followed-up regularly and did not receive neoadjuvant or adjuvant chemotherapy. We classified patients as having Gleason scores $\geq 7$ and $<7$, PSA values $\geq 10 \mathrm{ng} / \mathrm{ml}$ and $<10$, biochemical relapse positive or negative, T stages $\geq \mathrm{T} 2$ and $<\mathrm{T} 2$, tumor burden in less or more than $50 \%$ pathologic specimens, respectively. PSA cut-off value accepted was as $0.2 \mathrm{ng} / \mathrm{ml}$. According to average values in the literature, time to PSA relapses was considered early if it was less than 18 months and late if more than 18 months. We measured PSA and IGF-1 levels at each routine control visit.

Results: During 60-month follow-up, $66(80.4 \%)$ patients had no relapse, while in $8(9.8 \%)$ patients had early, and other $8(9.8 \%)$ patients had a late biochemical relapse. There was no statistically significant difference between these 3 groups of patients according to their age, tPSA levels, and BMI parameters. We compared IGF-1 levels with tumor burden, tPSA levels, tumor grade, and Gleason scores without any significant difference between these parameters. When we accepted IGF-1 cut-off values as $60 \mathrm{ng} / \mathrm{ml}$, we observed higher Gleason scores ( $\geq 7$ and more) in these patients. There was a weak relationship between IGF-1 levels of non-relapse and early relapse patients (p:0.078). However, when we evaluated IGF-1 levels among patients with relapse, the early relapse group had significantly higher IGF-1 levels (p: 0.006). When the cut-off value of IGF-1 was accepted as $60 \mathrm{ng} / \mathrm{ml}$, which was found to be significant for Gleason score, the early relapse group had significantly higher IGF-1 levels compared to the non-relapse group ( $\mathrm{p}: 0.023)$.

Conclusions: According to our study, the IGF-1 level has a predictive value for showing biochemical recurrence after surgery. Nevertheless, considering the number of patients, we need randomized controlled trials with a large number of patients.
\end{abstract}

Keywords: retropubic prostatectomy, prostate-specific antigen, insulin-like growth factor, prostate cancer

Öz

Amaç: İnsülin benzeri büyüme faktörü (IGF-1) seviyeleri prostat kanseri ile ilişkilendirilmiştir. Biz IGF-1 in prostat kanseri gelişimi üzerinde etkisi dışında küratif cerrahi geçirmiş ve cerrahi sınırı negatif olan hastalarda biyokimyasal nüksün önceden tahmininde katkısı olup olmayacağını araştırdık.

Gereçler ve Yöntemler: Neoadjuvan ve adjuvan tedavi almamış ve takibi yapıllabilmiş 82 hasta geriye dönük incelendi. Hastalar biyopsi ve patolojik spesmenlerin Gleason skorları $\geq 7 \mathrm{ve}<7$, PSA değerleri $\geq 10 \mathrm{ng} / \mathrm{ml}$ ve $<10$, biyokimyasal nüks olanlar ve olmayanlar, T evreleri $\geq \mathrm{T} 2$ ve $<\mathrm{T} 2$ olanlar, patolojik spesmende tümör yükü $\% 50$ altında ve üzerinde olanlar şeklinde ayrıldı. PSA kestirim değeri $0,2 \mathrm{ng} / \mathrm{ml}$ kabul edildi. PSA relaps süresi literatür ortalaması alınarak 18 ay altında erken, 18 ay üzerinde geç relaps olarak kabul edildi. Rutin kontrollerde PSA ve IGF-1 düzeyleri ölçüldü.

Bulgular: 60 aylık takipte $66(\% 80,4)$ hastada nüks izlenmezken, $8(\% 9.8)$ hastada erken biyokimyasal nüks ve $8(\% 9.8)$ hastada geç biyokimyasal nüks izlendi. Üç gruptaki hastaların arasında yaş, tPSA ve vücut kitle indeksi parametreleri arasında istatiksel olarak anlamlı fark yoktu. Tümör yükü, tPSA düzeyi, tümör evresi, gleason skorları ile IGF-1 düzeyleri karşılaştırıldı. Anlamlı fark izlenmedi. IGF-1 düzeyi için kestirim değeri $60 \mathrm{ng} / \mathrm{ml}$ alındığında bu değer üzerindeki hastaların yüksek gleason skorlarına (7 ve üstü) sahip olduğu izlendi. Nüks olmayan hastalar ile erken nüks gösteren hastalar arasında IGF-1düzeyleri açısından istatiksel olarak zayıf bir ilişki saptandı (p:0.078). IGF-1 seviyeleri nüks gösteren hastalar arasında değerlendirildiğinde erken nüks grubunda IGF-1 düzeyinin anlamlı olarak yüksek olduğu saptandı $(\mathrm{p}=0.006)$. Gleason skoru için anlamlı bulunan IGF-1 $60 \mathrm{ng} / \mathrm{ml}$ değeri kestirim değer alındığında IGF-1 düzeyi erken nüks grubunda, nüks göstermeyen gruba göre anlamlı olarak yüksek olduğu izlendi $(\mathrm{p}=0.023)$.

Sonuç: IGF-1 düzeyi cerrahi sonrası biyokimyasal nüksü göstermede bizler için prediktif bir değeri vardır. Fakat hasta sayısı göz önünde bulundurulduğu zaman, daha geniş çaplı hasta sayısına sahip randomize kontrollü çalışmalara ihtiyacımız vardır.

Anahtar kelimeler: retropubik prostatektomi, prostat spesifik antijen, insülin benzeri büyüme faktörü, prostat kanseri

ORCID ID: E. Uzun 0000-0002-3005-2122 C. Ceylan 0000-0001-5159-1291
B.B. Keseroglu 0000-0003-1124-2462

M.E. Polat

0000-0003-0271-0746
S. Tastemur 0000-0003-0534-2520

(C) Copyright 2021 by GJU. This journal is published by Logos Medical Publishing. This is an Open Access article distributed under the terms of the Creative Commons Attribution NonCommercial License (http://creativecommons.org/licenses/by-nc/4.0) which permits unrestricted non-commercial re-use, distribution, and reproduction in any medium, provided the original work is properly cited. 


\section{Introduction}

Prostate carcinoma ( $\mathrm{PCa}$ ) is one of the significant health issues in the male population. In Europe, 2.6 million people are diagnosed as cancer every year, and PCa accounts for $11 \%$ of all male cancers. Its incidence has increased rapidly after 1970 with the help of practical and accessible screening methods [1].

In carcinogenesis, inflammation, genetic, and multiple growth factors play an important role. Insulin is essential for both energy metabolism and glucose regulation. Also, it may have a role in $\mathrm{PCa}$ development because of its potent mitogenic and growth factor-like effects [2].

Insulin has a suppressive effect on insulin-like growth factor binding protein (IGFBP-1) secretion. Moreover, according to this relation, IGFBP-1 levels might be an essential factor for insulin activity on the target tissue [3]. Besides the effect of insulin on tissues, IGFBP-1 binds to insulin-like growth factor (IGF-1) with high affinity and decreases its level and effect [4]. In epidemiologic studies, low-risk PCas, are mostly related to high IGF-1 plasma levels. However, it is not definite whether IGF-1 and insulin interrelation causes PCa development or not [5].

Positive surgical margin (PSM) detected in pathology specimens after radical prostatectomy (RP) was accepted as a poor prognostic factor and has been reported as $10 \%$ in articles about RP. Both pathologic and biochemical findings have been investigated for estimation of biochemical recurrence in noninvasive cases after RP. According to recent studies, total tumor volumes and maximum tumor diameters are not enough to predict biochemical recurrence [6].

In this study, we aimed to find the contribution of IGF1 levels in predicting biochemical relapse of RP patients with negative surgical margins (NSM).

\section{Materials and Methods}

In this study, we analyzed RP patients operated for $\mathrm{PCa}$ between May 2009 and June 2014 in Turkiye Yuksek Ihtisas Training and Research Hospital after obtaining approval from Education Plan and Coordination Board (Approval Number: 2014/B.10.4.ISM.4.06.00.15). RP was applied to 240 patients in this period, and positive surgical margins (PSMs) were detected in 14 of them. We analyzed 82 patients who had negative surgical margins (NSM) in pathology specimens and continued their prostatespecific antigen (PSA) controls regularly. Also, these 82 patients were not treated with neoadjuvant or adjuvant chemoradiotherapy.

PCa patients were classified as having Gleason scores $\geq 7$ and $<7$, PSA values $\geq 10 \mathrm{ng} / \mathrm{ml}$ and $<10$, biochemical relapse positive or negative, $\mathrm{T}$ stages $\geq \mathrm{T} 2$ and $<\mathrm{T} 2$, and tumor burden in pathologic specimens less and more than $50 \%$, respectively. PSA cut-off value was accepted as $0,2 \mathrm{ng} / \mathrm{ml}$. According to average values in the literature, time to PSA relapse was considered early if it was less than 18 months and late if more than 18 months. All control PSA tests of the patients were studied and analyzed with Human PSA ELISA Kit, 96 tests, Quantitative. We also measured free IGF-1 levels with ELISA tests in Yildirim Beyazit University, Laboratory of Biochemistry Department.

\section{Statistical Analysis}

For statistical analyses, IBM SPSS version 22.0 (SPSS Inc, Chicago, IL) for Windows was used. Descriptive data were defined as number, percentage, mean \pm standard deviation. Normal distribution of data was tested with the KolmogorovSmirnov test. Mann-Whitney U test was used for the analysis of quantitative data that did not show normal distribution. KruskalWallis Test was used to analyze quantitative data of more than 2 groups that did not show normal distribution. For qualitative data, chi-square test, and when chi-square assumptions were not met, Fisher's exact test was used. The ability of IGF-1 to predict the presence of relapse was evaluated by receiver operating characteristic (ROC) curve analysis and area under curve (AUC) values of the analysis were presented. Cut-off values were calculated according to Youden index. $\mathrm{p}<0.05$ was considered statistically significant.

\section{Results}

Eighty-two RP patients with NSM were evaluated in this study. In the 60-month follow-up, $66(80,4 \%)$ patients had no relapse, while in $8(9,8 \%)$ patients early, and in other $8(9.8 \%)$ patients late biochemical relapses were observed. We evaluated patients in 3 groups according to their relapsing times. There was no statistically significant difference between these 3 patient groups according to their age, total PSA (tPSA) levels, and body mass index (BMI) parameters (Table 1).

We compared IGF-1 levels with tumor burden, tPSA levels, tumor grade, Gleason scores detected in biopsy materials, and tumor specimens (GSs), without any significant difference between these parameters. When we accepted IGF-1 cut-off value as $60 \mathrm{ng} / \mathrm{ml}$, we detected higher Gleason scores $(\geq 7)$ (specimen GS $\mathrm{p}=0.011$; biopsy GS $\mathrm{p}=0.017$ ) in these patients (Table 2). There was statistically weak relationship between non-relapse and early relapse patients in terms of IGF-1 levels (p: 0.078) (Table 3).

However, when we compared IGF-1 levels between the relapse groups, the early relapse group had higher IGF-1 levels significantly (p: 0.006) and also, this association had high

Table 1. Distribution of age, PSA, BMI of all study patients

\begin{tabular}{l|l|l|l|l}
\hline & No Relapse & Early Relapse & Late Relapse & P value \\
\hline Age $($ years $)$ & $64.8 \pm 7.8$ & $65.2 \pm 6.4$ & $65.5 \pm 7.5$ & 0.33 \\
\hline Total PSA $(\mathrm{ng} / \mathrm{mL})$ & $9.9 \pm 5.7$ & $10.1 \pm 5.9$ & $9.1 \pm 3.7$ & 0.49 \\
\hline BMI $\left(\mathrm{kg} / \mathrm{m}^{2}\right)$ & $27.4 \pm 3.3$ & $28.2 \pm 4.2$ & $27.3 \pm 3.2$ & 0.21 \\
\hline
\end{tabular}


sensitivity and specificity in ROC analysis (Figure 1).

The non-relapse and relapse groups were compared again using a cut-off value of $60 \mathrm{ng} / \mathrm{ml}$. IGF-1 levels of most of the patients in the early relapse group were more than $60 \mathrm{ng} / \mathrm{ml}(\mathrm{p}$ : 0.023 ). We did not observe a significant difference between the late relapse and the non-relapse groups in terms of IGF-1 levels $(\mathrm{p}=0.12)$ (Table 3).

Finally, a statistically significant difference existed between early relapse and non-relapse groups in terms of IGF-1 levels with high degrees of sensitivity and specificity (Figure 2).

\section{Discussion}

PCa is one of the most prevalent tumors in the male population. While it's incidence increases with age, it constitutes $15 \%$ of carcinomas seen in male population [7]. Although the incidence of PCa has increased 4 times in the last 30 years, mortality rates have decreased significantly in the last 20 years thanks to detection of the disease at an early stage using disgnostic markers such as PSA [8].
RP a curative treatment for localized PCa patients. Surgical technique has improved with the help of technologic developments during the last 10 years. But biochemical relapse still a problem in $27-53 \%$ of these patients [9]. Although biochemical relapse is mostly seen as local recurrence, it can also manifest as symptomatic or asymptomatic systemic disease. Increase in biochemical values indicate PCa recurrence but may not have an effect on quality of life and overall survival. The purpose of biochemical relapse control is to prevent development of metastatic disease and decrease metastasis-related morbidity and mortality rates. Also, we can avoid unnecessary adjuvant therapy in PCa patients with low risk of disease progression [10].

There are many reasons directly or indirectly related to $\mathrm{PCa}$ development [11]. IGF-1 and its binding proteins are produced in healthy and carcinomatous prostate tissues, and stimulate cellular proliferation with IGF-1 receptor activation [12]. While some studies report that IGF-1 levels are high in PCa patients [13], there are also studies that do not support this $[14,15]$.

In a study investigating IGF-1 levels in PCa patients, the

Table 2. Distribution of IGF-1 values, tumor burden, stage, tPSA, and GS

\begin{tabular}{|c|c|c|c|c|c|}
\hline & $\begin{array}{l}\text { IGF-1 mean } \\
(\mathrm{ng} / \mathrm{ml}) \\
(\mathrm{n})\end{array}$ & P value & $\begin{array}{l}\text { IGF-1 } \\
<60 \mathrm{ng} / \mathrm{ml} \\
\text { (n) }\end{array}$ & $\begin{array}{l}\text { IGF-1 } \\
\geq 60 \mathrm{ng} / \mathrm{ml} \\
\text { (n) }\end{array}$ & P value \\
\hline $\begin{array}{l}\text { TM Burden } \\
\leq 50 \%\end{array}$ & $\begin{array}{l}63 \\
(40.8)\end{array}$ & \multirow{2}{*}{0.65} & 58 & 5 & \multirow{2}{*}{0.2} \\
\hline $\begin{array}{l}\text { TM Burden } \\
>50 \%\end{array}$ & $\begin{array}{l}19 \\
(47.2)\end{array}$ & & 15 & 4 & \\
\hline $\mathrm{T} 2 \leq$ & $\begin{array}{l}54 \\
(41.6)\end{array}$ & \multirow{2}{*}{0.96} & 50 & 4 & \multirow{2}{*}{0.26} \\
\hline$>\mathrm{T} 2$ & $\begin{array}{l}28 \\
(43.5)\end{array}$ & & 23 & 5 & \\
\hline $\mathrm{tPSA} \leq 10 \mathrm{ng} / \mathrm{mL}$ & $\begin{array}{l}58 \\
(41.1)\end{array}$ & \multirow{2}{*}{0.43} & 50 & 8 & \multirow{2}{*}{0.19} \\
\hline $\mathrm{tPSA}>10 \mathrm{ng} / \mathrm{mL}$ & $\begin{array}{l}24 \\
(44.2)\end{array}$ & & 21 & 3 & \\
\hline Biopsy GS 7< & $\begin{array}{l}52 \\
(40.9) \\
\end{array}$ & \multirow{2}{*}{0.75} & 49 & 3 & \multirow{2}{*}{0.011} \\
\hline Biopsy GS $\geq 7$ & $\begin{array}{l}30 \\
(46.6) \\
\end{array}$ & & 8 & 22 & \\
\hline Specimen GS 7< & $\begin{array}{l}51 \\
(41.9) \\
\end{array}$ & \multirow{2}{*}{0.99} & 46 & 5 & \multirow{2}{*}{0.017} \\
\hline Specimen GS $\geq 7$ & $\begin{array}{l}31 \\
(43.8)\end{array}$ & & 11 & 20 & \\
\hline
\end{tabular}

TM: tumor; GS: Gleason score; tPSA: total prostate specific antigen; IGF-1: insulin-like growth factor -1; n: number of patients 
Table 3. Comparison of patient groups according to IGF-1 levels

\begin{tabular}{|c|c|c|c|c|c|}
\hline & $\begin{array}{l}\text { IGF-1 mean } \\
(\mathrm{ng} / \mathrm{ml}) \\
(\mathrm{n})\end{array}$ & P value & $\begin{array}{l}\text { IGF-1 } \\
<60 \mathrm{ng} / \mathrm{ml} \\
\text { (n) }\end{array}$ & $\begin{array}{l}\text { IGF-1 } \\
\geq 60 \mathrm{ng} / \mathrm{ml} \\
\text { (n) }\end{array}$ & Pvalue \\
\hline No Relapse & $\begin{array}{l}66 \\
(41.1)\end{array}$ & \multirow{2}{*}{0.078} & 60 & 6 & \multirow[b]{2}{*}{0.023} \\
\hline Early Relapse & $\begin{array}{l}8 \\
(63.9) \\
\end{array}$ & & 1 & 7 & \\
\hline No Relapse & $\begin{array}{l}66 \\
(41.1)\end{array}$ & \multirow{2}{*}{0.177} & 60 & 6 & \multirow[b]{2}{*}{0,12} \\
\hline Late Relapse & $\begin{array}{l}8 \\
(31.2)\end{array}$ & & 5 & 3 & \\
\hline Early Relapse & $\begin{array}{l}8 \\
(63.9)\end{array}$ & \multirow{2}{*}{0.006} & & & \\
\hline Late Relapse & $\begin{array}{l}8 \\
(31.2)\end{array}$ & & & & \\
\hline
\end{tabular}

IGF-1: insulin-like growth factor -1; n: number of patients

patients were grouped according to their specimen GSs. PCa patients with low-grade GSs $(\mathrm{GS}<7)$ had significantly higher IGF-1 levels than the control group, but any significant difference was not detected in terms of IGF-1 levels between PCa patients with low-, and high-grade GSs (GS $\geq 7$ ) PCa patients did not have a significant difference. Also, in localized PCa patients, IGF-1 levels were correlated with the disease grade. However any difference was not detected between locally advanced and metastatic PCa patients as for IGF-1 levels in this study [16].

When we did not specified the cut-off value for IGF-1 in our study, there was no significant correlation between IGF-1 levels and GSs of specimens or biopsy materials. However, if we specified the cut-off value as $60 \mathrm{ng} / \mathrm{ml}$, both biopsy material and specimen GS's were significantly higher in patients with IGF-1 levels above $60 \mathrm{ng} / \mathrm{ml}$ (specimen GS p=0.011; biopsy material GS $\mathrm{p}=0.017$ ).

Koliakos et al. investigated 147 patients with $\mathrm{PCa}$ and benign prostate hyperplasia (BPH) for the effect of IGF-1 levels on the early diagnosis of PCa patients. There was no difference between IGF-1 levels, but the free/total (f/t) PSA ratio was lower in the PCa group. They used this result for its correlation with PSA/ IGF-1 level. PCa patients had significantly higher PSA/IGF-1 levels $(\mathrm{p}=0.002)$. But, for the BPH group, the correlation was weak ( $\mathrm{P}=0.042)$. According to $\mathrm{ROC}$ analysis, as a screening test for PCa, PSA/IGF-1 level had higher sensitivity and specificity than PSA and $\mathrm{f} / \mathrm{t} \mathrm{PSA}$ ratio [17].

Nam et al. measured IGF-1 levels in precancerous prostatic patients. High-grade prostatic intraepithelial neoplasia (HGPIN) detected in biopsy materials was accepted as a precancerous pathology. Their IGF-1 levels were significantly higher than the control group $(\mathrm{p}=0.01)$ [18].

In our study, in addition to the effect of IGF-1 levels on the PSA relapse in cured PCa patients, we also calculated correlations of IGF-1 levels with T stage, total PSA levels, and tumor burden in specimens in the same group. As a result, IGF-1 values higher than $60 \mathrm{ng} / \mathrm{ml}$ had a weak correlation with increased tumor burden and high $\mathrm{T}$ stage. However, any statistically significant correlation with total PSA levels was not detected.

Many studies have investigated the relationship between pathogenesis of PCa, and IGF-1. However, there are few studies on biochemical relapse after RP and its relationship with IGF1. Guidelines have determined the cut-off value of biochemical relapse after RP as $0.2 \mathrm{ng} / \mathrm{ml}$. Times to early or late relapse have not been standardized in the literature. Various studies accept this period as 3 to 36 months [19].

Shahabi et al. have searched risk factors for biochemical relapse in 2262 RP patients. These patients had not received any neoadjuvant or adjuvant treatment (pT2-3N0M0) [20]. In this study, they accepted the first 35 months after RP as early relapse and more than 35 months as late relapse. They found an association between early relapse, GS $\geq 7, \mathrm{PSM}$, and $\geq \mathrm{pT} 3 \mathrm{a}$ stages. Besides, late relapse was associated with GS $7(4+3)$, high preoperative PSA level, and $\geq \mathrm{pT} 3$ a stage in the same study.

According to the literature, we accepted the relapse time classification limit as 18 months. IGF-1 levels in non-relapse and late relapse groups were not statistically different. There was a weak correlation between the early relapse and the nonrelapse group. However, when the early and the late relapse groups were compared a significantly higher IGF-1 levels were found in the early relapse group ( $\mathrm{p}=0.006$ ).

Also, we investigated cut-off IGF-1 levels for biochemical relapse risk factors. When we accepted $60 \mathrm{ng} / \mathrm{ml}$ for a cut-off value for IGF-1 which was significant as for GSs, IGF-1 levels were higher in the early relapse group compared to the nonrelapse group $(\mathrm{p}=0.023)$. 


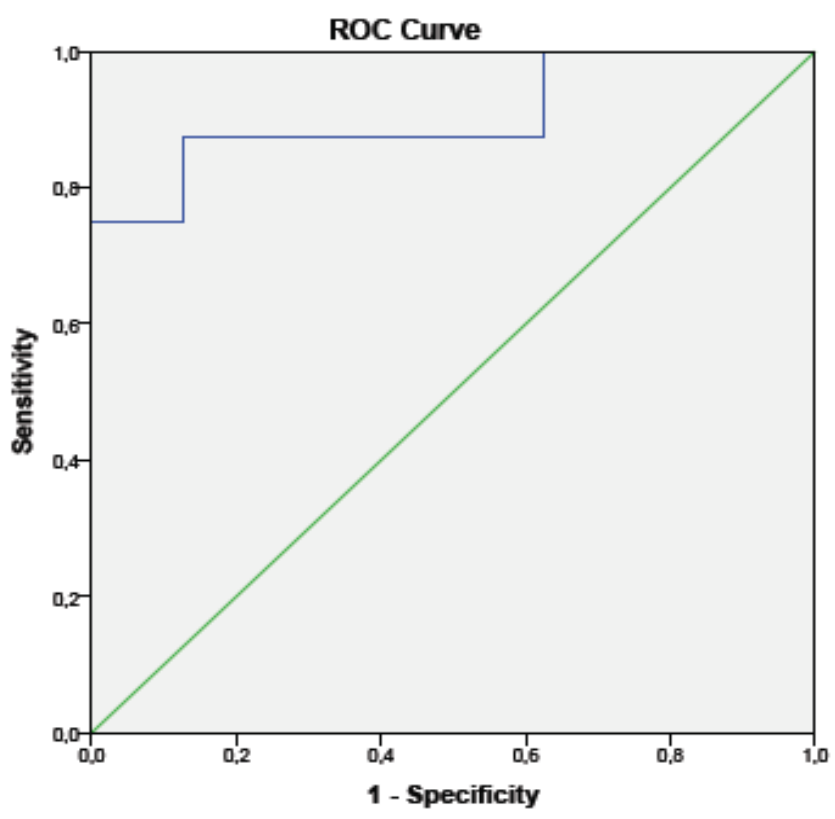

Figure 1. Relationship between early, and late relapse groups as for IGF-1 levels

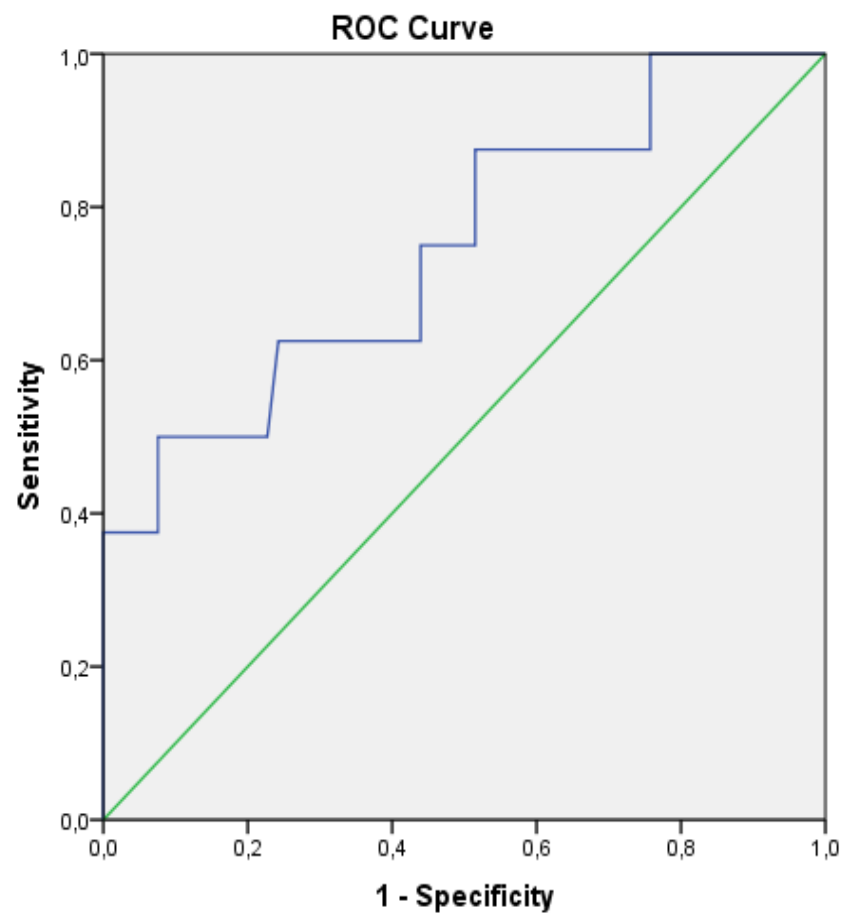

Diagonal segments are produced by ties.

Figure 2. Relationship between early, and late relapse groups as for IGF-1 levels (cut-off for IGF-1 $60 \mathrm{ng} / \mathrm{ml}$ )

Our study also has limitations. First of all, our study was designed retrospectively. In addition, the small number of patients is one of the limitations.

\section{Conclusion}

In conclusion, success rates of localized PCa treatment increase with the development of surgical techniques and medical technology. Evaluation of biochemical relapse after surgery also affects the success of treatment. Lots of biochemical parameters, hormonal and genetic risk factors have been evaluated in terms of treatment success. In our study, PCa patients with NSMs who underwent RP were analyzed. The relationship between IGF-1 levels and biochemical relapse was investigated. We observed that if the IGF-1 level was high, risk of early biochemical relapse increased. According to this result, IGF-1 is valuable for predicting biochemical relapse in the patients' follow-up.

Ethics Committee Approval: The study was approved by Turkey Yuksek Ihtisas Training and Research Hospital Education Plan and Coordination Board, Cankaya, Ankara, Turkey (Decision No: 03 July 2014/B.10.4.ISM.4.06.00.15).

Informed Consent: An informed consent was obtained from all the patients.

Publication: The results of the study were not published in full or in part in form of abstracts.

Peer-review: Externally peer-reviewed.

Authorship Contributions: Any contribution was not made by any individual not listed as an author. Concept - Y.K., E.U.; B.B.K, M.E.P.; Design - Y.K., E.U., B.B.K, M.E.P.; Supervision - Y.K., E.U., C.C., M.E.P.; Resources - Y.K., E.U., B.B.K, M.E.P.; Materials - Y.K., E.U., B.B.K, M.E.P.; Data Collection and/or Processing - Y.K., E.U., B.B.K, M.E.P.; Analysis and/or Interpretation - Y.K., E.U., B.B.K, S.T., C.C., M.E.P.; Literature Search-Y.K., E.U., B.B.K, M.E.P.; Writing - Y.K., E.U., B.B.K, S.T.; Critical Review - Y.K., S.T., C.C., M.E.P.

Conflict of Interest: The authors declare that they have no conflict of interest.

Financial Disclosure: The authors have declared that they did not receive any financial support for the realization of this study.

\section{References}

[1] Bray F, Sankila R, Ferlay J, Parkin DM. Estimates of cancer incidence and mortality in Europe in 1995. Eur J Cancer 2002;38:99-166. https://doi.org/10.1016/S0959-8049(01)00350-1.

[2] Holly JMP, Biernacka K, Perks CM. The role of insulinlike growth factors in the development of prostate cancer. Expert Rev Endocrinol Metab 2020;15:237-50. https://doi.org/10.1080/17446651.2020.1764844.

[3] Johansson M, McKay JD, Wiklund F, Rinaldi S, Verheus $\mathrm{M}$, Van Gils $\mathrm{CH}$, et al. Implications for prostate cancer of insulin-like growth factor-I (IGF-I) genetic variation and circulating IGF-I levels. J Clin Endocrinol Metab 2007;92:4820-6. https://doi.org/10.1210/jc.2007-0887.

[4] Rowlands MA, Gunnell D, Harris R, Vatten LJ, Holly JMP, Martin RM. Circulating insulin-like growth factor peptides and prostate cancer risk: A systematic review and meta-analysis. Int J Cancer 2009;124:2416-29. https://doi.org/10.1002/ijc.24202.

[5] Patel AV, Cheng I, Canzian F, Le Marchand L, Thun MJ, Berg CD, et al. IGF-1, IGFBP-1 and IGFBP-3 polymorphisms predict circulating IGF levels but not breast cancer risk: Findings from the breast and prostate cancer cohort consortium (BPC3). PLoS One 2008;3:e2578. https://doi.org/10.1371/journal.pone.0002578. 
[6] Preisser F, Coxilha G, Heinze A, Oh S, Chun FKH, Sauter $\mathrm{G}$, et al. Impact of positive surgical margin length and Gleason grade at the margin on biochemical recurrence in patients with organ-confined prostate cancer. Prostate 2019;79:1832-6. https://doi.org/10.1002/pros.23908.

[7] Jemal A, Bray F, Center MM, Ferlay J, Ward E, Forman D. Global cancer statistics. CA Cancer J Clin 2011;61:69-90. https://doi.org/10.3322/caac.20107.

[8] Barry MJ, Simmons LH. Prevention of Prostate Cancer Morbidity and Mortality: Primary Prevention and Early Detection. Med Clin North Am 2017;101:787-806. https://doi.org/10.1016/j.mcna.2017.03.009.

[9] Mottet N, Bellmunt J, Bolla M, Briers E, Cumberbatch MG, De Santis M, et al. EAU-ESTRO-SIOG Guidelines on Prostate Cancer. Part 1: Screening, Diagnosis, and Local Treatment with Curative Intent. Eur Urol 2017;71:618-29. https://doi.org/10.1016/j.eururo.2016.08.003.

[10] Artibani W, Porcaro AB, De Marco V, Cerruto MA, Siracusano S. Management of Biochemical Recurrence after Primary Curative Treatment for Prostate Cancer: A Review. Urol Int 2018;100:251-62. https://doi.org/10.1159/000481438.

[11] Merriel SWD, Funston G, Hamilton W. Prostate Cancer in Primary Care. Adv Ther 2018;35:1285-94. https://doi.org/10.1007/s12325-018-0766-1.

[12] Ahearn TU, Peisch S, Pettersson A, Ebot EM, Zhou CK, Graff RE, et al. Expression of IGF/insulin receptor in prostate cancer tissue and progression to lethal disease. Carcinogenesis 2018;39:1431-7. https://doi.org/10.1093/carcin/bgy112.

[13] Kim M, Kim JW, Kim JK, Lee SM, Song C, Jeong IG, et al. Association between serum levels of insulin-like growth factor-1, bioavailable testosterone, and pathologic Gleason score. Cancer Med 2018;7:4170-80. https://doi.org/10.1002/cam4.1681.

[14] Finne P, Auvinen A, Koistinen H, Zhang W-M, Määttänen L, Rannikko S, et al. Insulin-Like Growth Factor I Is Not a Useful Marker of Prostate Cancer in Men with Elevated Levels of Prostate-Specific Antigen1. J Clin Endocrinol Metab 2000;85:2744-7. https://doi.org/10.1210/jcem.85.8.6725.
[15] Kurek R, Tunn UW, Eckart O, Aumüller G, Wong J, Renneberg $\mathrm{H}$. The significance of serum levels of insulinlike growth factor- 1 in patients with prostate cancer. BJU Int 2000;85:125-9. https://doi.org/10.1046/j.1464-410X.2000.00350.x.

[16] Nimptsch K, Platz EA, Pollak MN, Kenfield SA, Stampfer MJ, Willett WC, et al. Plasma insulin-like growth factor 1 is positively associated with low-grade prostate cancer in the Health Professionals Follow-up Study 1993-2004. Int J Cancer 2011;128:660-7. https://doi.org/10.1002/ijc.25381.

[17] Koliakos G, Chatzivasiliou D, Dimopoulos T, Trachana V, Paschalidou K, Galiamoutsas V, et al. The significance of PSA/IGF-1 ratio in differentiating benign prostate hyperplasia from prostate cancer. Dis Markers 2000;16:143-6. https://doi.org/10.1155/2000/764851.

[18] Nam RK, Trachtenberg J, Jewett MAS, Toi A, Evans A, Emami M, et al. Serum insulin-like growth factor-I levels and prostatic intraepithelial neoplasia: A clue to the relationship between IGF-I physiology and prostate cancer risk. Cancer Epidemiol Biomarkers Prev 2005;14:1270-3. https://doi.org/10.1158/1055-9965.EPI-04-0430.

[19] Han M, Piantadosi S, Zahurak ML, Sokoll LJ, Chan DW, Epstein JI, et al. Serum acid phosphatase level and biochemical recurrence following radical prostatectomy for men with clinically localized prostate cancer. Urology 2001;57:707-11. https://doi.org/10.1016/S0090-4295(00)01073-6.

[20] Shahabi A, Satkunasivam R, Gill IS, Lieskovsky G, Daneshmand S, Pinski JK, et al. Predictors of time to biochemical recurrence in a radical prostatectomy cohort within the PSA-era. Can Urol Assoc J 2016;10:E17-22. https://doi.org/10.5489/cuaj.3163. 